\title{
Glioblastoma Multiforme versus Solitary Supratentorial Brain Metastasis: Differentiation Based on Morphology and Magnetic Resonance Signal Characteristics
}

\author{
Glioblastoma multiforme versus singuläre supratentorielle Hirnmetastasen: Differenzierung mittels \\ Morphologie und Magnetresonanz-Signalcharakteristika
}

Authors

Affiliations
M. H. Maurer ${ }^{1}$, M. Synowitz ${ }^{2}$, H. Badakshi ${ }^{3}$ L. N. Lohkamp ${ }^{2}$, J. Wüstefeld ${ }^{1}$, M.-L. Schäfer ${ }^{1}$, E. Wiener ${ }^{1}$

Klinik für diagnostische und interventionelle Radiologie, Charité - Universitätsmedizin Berlin

Klinik für Neurochirurgie, Charité - Universitätsmedizin Berlin

3 Klinik für Strahlentherapie, Charité - Universitätsmedizin Berlin
Key words

- glioblastoma multiforme

- brain metastases

- multi-factor analysis

- morphologic criteria

- magnetic resonance imaging

eingereicht 16.8 .2012

akzeptiert $\quad 17.10 .2012$

Bibliography

DOI http://dx.doi.org/

10.1055/s-0032-1330318

Published online: 29.11.2012

Fortschr Röntgenstr 2013; 185 :

235-240 @ Georg Thieme

Verlag KG Stuttgart · New York .

ISSN 1438-9029

\section{Correspondence}

\section{Dr. Martin H Maurer}

Klinik für diagnostische und interventionelle Radiologie,

Charité - Universitätsmedizin Berlin

Charité Campus Virchow-

Klinikum,

Augustenburger Platz 1

13353 Berlin

Germany

Tel.: ++ 49/30/450657177

Fax: ++49/30/450557901

martin.maurer@charite.de

\section{Zusammenfassung \\ $\nabla$}

Ziel: Evaluation der diagnostischen Wertigkeit einer multifaktoriellen Analyse zur Differenzierung solitärer supratentorieller Hirnmetastasen von einem Glioblastoma multiforme (GBM) unter Berücksichtigung morphologischer Parameter und magnetresonanztomografischer Signalcharakteristika der Tumormasse und der peritumoralen Zone.

Material und Methoden: Magnetresonanztomografie(MRT)-Untersuchungen von 51 Patienten mit einem jeweils histologisch gesicherten GBM und 44 Patienten mit einer singulären supratentoriellen Hirnmetastase wurden evaluiert. Hierbei wurde eine Vielzahl morphologischer Kriterien und MRTSignalcharakteristika in verschiedenen Sequenzen analysiert. Mittels einer logistischen Regressionsanalyse wurde die Wertigkeit der verschiedenen Kriterien zur Differenzierung zwischen einem GBM und einer singulären Metastase untersucht. Mit einer Receiver-Operating-Characteristics(ROC)-Analyse wurde ein optimaler Schwellenwert zur Vorhersage ermittelt unter Berücksichtigung der Sensitivität, Spezifität und Genauigkeit des finalen Modells.

Ergebnisse: Die logistische Regressionsanalyse ergab, dass das Verhältnis des maximalen Durchmessers des peritumoralen Areals in T2-gewichteten Sequenzen (d T2) im Verhältnis mit dem maximalen Durchmesser der kontrastmittelaufnehmenden Tumormasse ( $\mathrm{d} \mathrm{T} 1$, post contrast) das einzige dienliche Kriterium zur Differenzierung einer singulären supratentoriellen Metastase von einem GBM darstellt (Genauigkeit 68\%, Sensitivität $84 \%$ und Spezifität $45 \%$ ). Der Schwellenwert für das Verhältnis d T2/d $\mathrm{T} 1$, post contrast betrug 2,35.

Schlussfolgerung: Das Verhältnis aus den maximalen Durchmessern des peritumoralen Areals und der kontrastmittelaufnehmenden Tumormasse kann in der klinischen Routine einfach erfasst werden und ermöglicht bei der Differenzierung von singulären Hirnmetastasen und GBM eine Genauigkeit ähnlich derjenigen neuester MRT-Techniken.

\section{Abstract \\ $\nabla$}

Purpose: To evaluate the diagnostic potential of a multi-factor analysis of morphometric parameters and magnetic resonance (MR) signal characteristics of a mass and peritumoral area to distinguish solitary supratentorial metastasis from glioblastoma multiforme (GBM).

Materials and Methods: MR examinations of 51 patients with histologically proven GBM and 44 with a single supratentorial metastasis were evaluated. A large variety of morphologic criteria and MR signal characteristics in different sequences were analyzed. The data were subjected to logistic regression to investigate their ability to discriminate between GBM and cerebral metastasis. Receiver-operating characteristic (ROC) analysis was used to select an optimal cut-off point for prediction and to assess the predictive value in terms of sensitivity, specificity, and accuracy of the final model.

Results: The logistic regression analysis revealed that the ratio of the maximum diameter of the peritumoral area measured on T2-weighted images (d T2) to the maximum diameter of the enhancing mass area (d T1, post-contrast) is the only useful criterion to distinguish single supratentorial brain metastasis from GBM with a lower ratio favoring GBM (accuracy $68 \%$, sensitivity $84 \%$ and specificity $45 \%$ ). The cut-off point for the ratio d T2/d T1 post-contrast was calculated as 2.35. Conclusion: Measurement of maximum diameters of the peritumoral area in relation to the enhancing mass can be evaluated easily in the clinical routine to discriminate GBM from solitary supratentorial metastasis with an accuracy comparable to that of advanced MRI techniques. 


\section{Introduction}

$\nabla$

Glioblastoma multiforme (GBM) and cerebral metastasis are the most common malignant brain tumors [1]. Differentiation is very important for planning further diagnostic workup and treatment [2-5]. Most of the patients will still require a biopsy for definitive diagnosis even when there is a history of a known primary malignancy.

While the diagnosis of metastasis is usually straightforward in patients with multiple or infratentorial brain lesions, differentiation is often difficult when patients present with a solitary enhancing supratentorial lesion. Even with advanced MR techniques including MR spectroscopy (MRS) [6-8], diffusion tensor imaging (DTI) [9] and perfusion MRI [10, 11], differential diagnosis remains a challenge with most investigators reporting an accuracy of less than $65 \%[6,12-14]$.

A way to make a reliable distinction between these two entities based on MR imaging findings might be a multi-factor analysis of morphometric parameters and signal characteristics of the mass area and peritumoral area. In metastases the peritumoral area consists essentially of vasogenic edema, while in GBM, this may also contain neoplastic cells $[9,15]$. Thus, in GBM, a relative decrease in peritumoral T2- or fluid-attenuated inversion recovery (FLAIR) hyperintense signal intensity may be expected compared with metastasis [12]. In metastatic lesions restricted diffusion can be observed in about $20 \%$ of cases [16], while the vast majority of GBM do not exhibit restricted diffusion.

The purpose of this study was to evaluate the diagnostic potential of a multi-factor analysis of morphometric parameters and T1, T2, FLAIR, T2 fast field echo (T2 FFE), diffusion-weighted imaging (DWI) and post-contrast signal characteristics of the peritumoral and mass area to distinguish solitary supratentorial metastasis from GBM.

\section{Materials and Methods}

$\nabla$

\section{Patients}

During the period from December 2008 through April 2010, we identified all patients with a single supratentorial ring-enhancing lesion on the basis of MRI of the head and subsequent biopsy ( $\bullet$ Table 1). The patients included in the analysis had either a single primary GBM (WHO grade IV) or a solitary cerebral metastasis from a known primary tumor ( $\bullet$ Fig. 1 ). A final histopathology report was available for all patients. Patients with more than one cerebral lesion or infratentorial lesions were not included. Also excluded were patients in whom the MRI appearance already suggested the type of tumor, e.g., metastasis from malignant melanoma with an increased melanin content demonstrated as hyperintensity on unenhanced T1-weighted images.

\section{Data acquisition}

All MRI examinations of the head were performed on a 1.5-Tesla MR scanner using an 8-channel head coil (Philips Medical Systems, Gyroscan NT CompactPlus, Amsterdam, Netherlands). The following pulse sequences were acquired: axial T2-weighted sequence (TE $120 \mathrm{~ms}$, TR $5800 \mathrm{~ms}$, slice thickness $5 \mathrm{~mm}$ ), axial T2weighted FLAIR sequence (TE $150 \mathrm{~ms}$, TR $6000 \mathrm{~ms}$, inversion time $2 \mathrm{~s}, 5 \mathrm{~mm}$ ), axial T1-weighted spin echo sequence (TE $14 \mathrm{~ms}$, TR $565 \mathrm{~ms}, 5 \mathrm{~mm}$ ), blood-sensitive T2-weighted FFE (TE $30 \mathrm{~ms}$, TR $830 \mathrm{~ms}, 5 \mathrm{~mm}$ ), and DWI sequence (TE $84 \mathrm{~ms}$, TR $3500 \mathrm{~ms}, 5 \mathrm{~mm}$ ). Following administration of contrast medium (gadobutrol $0.1 \mathrm{mmol} / \mathrm{kg}$, Gadovist ${ }^{\circledR}$, Bayer Healthcare, Berlin, Germany), axial, coronal, and sagittal T1-weighted sequences were acquired (TE $14 \mathrm{~ms}$, TR $565 \mathrm{~ms}, 5 \mathrm{~mm}$ ).

Table 1 Study population with a GBM or a cerebral metastasis from different primaries.

Tab. 1 Patientenkollektiv mit einem GBM oder einer zerebralen Metastase mit unterschiedlichem Primärtumor.

\begin{tabular}{|c|c|}
\hline \multicolumn{2}{|l|}{ patients with GBM $(n=51)$} \\
\hline men & 29 \\
\hline women & 22 \\
\hline mean age ( \pm standard deviation) & $62.4 \pm 12.8$ years \\
\hline \multicolumn{2}{|c|}{$\begin{array}{l}\text { patients with single cerebral metastasis } \\
(n=44)\end{array}$} \\
\hline men & 22 \\
\hline women & 22 \\
\hline mean age ( \pm standard deviation) & $60.2 \pm 12.4$ years \\
\hline \multicolumn{2}{|l|}{ primary tumor: } \\
\hline malignant melanoma & $18^{1}$ \\
\hline gastrointestinal adenocarcinoma & 16 \\
\hline lung cancer & 3 \\
\hline renal cell carcinoma & 3 \\
\hline breast cancer & 2 \\
\hline ovarian cancer & 1 \\
\hline differentiated neuroendocrine tumor & 1 \\
\hline
\end{tabular}

Ohne T1w-Hyperintensitäten.
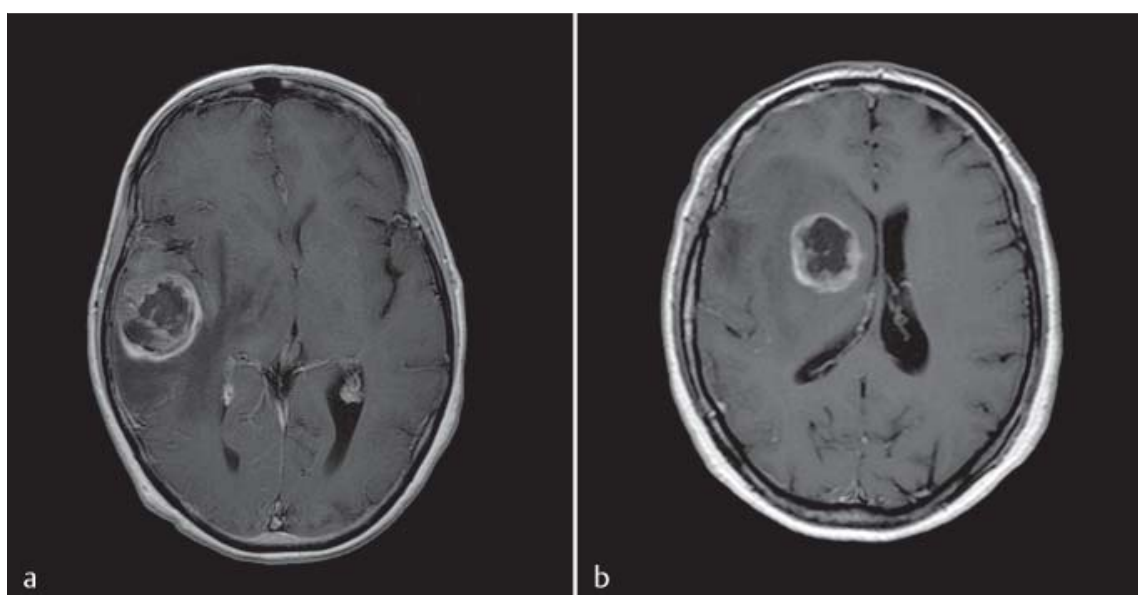

Fig. 1 Single cerebral lesion: metastasis from bronchial carcinoma a and glioblastoma multiforme b. After contrast administration both lesions show strong ring enhancement, which precludes reliable differentiation of the two entities.

Abb. 1 Singuläre zerebrale Läsionen: Metastase eines Bronchialkarzinoms a und ein Glioblastoma multiforme b. Nach Kontrastmittelapplikation zeigen beide Läsionen ein kräftiges randständiges Enhancement; eine Differenzierung beider Tumorentitäten ist zunächst nicht möglich. 

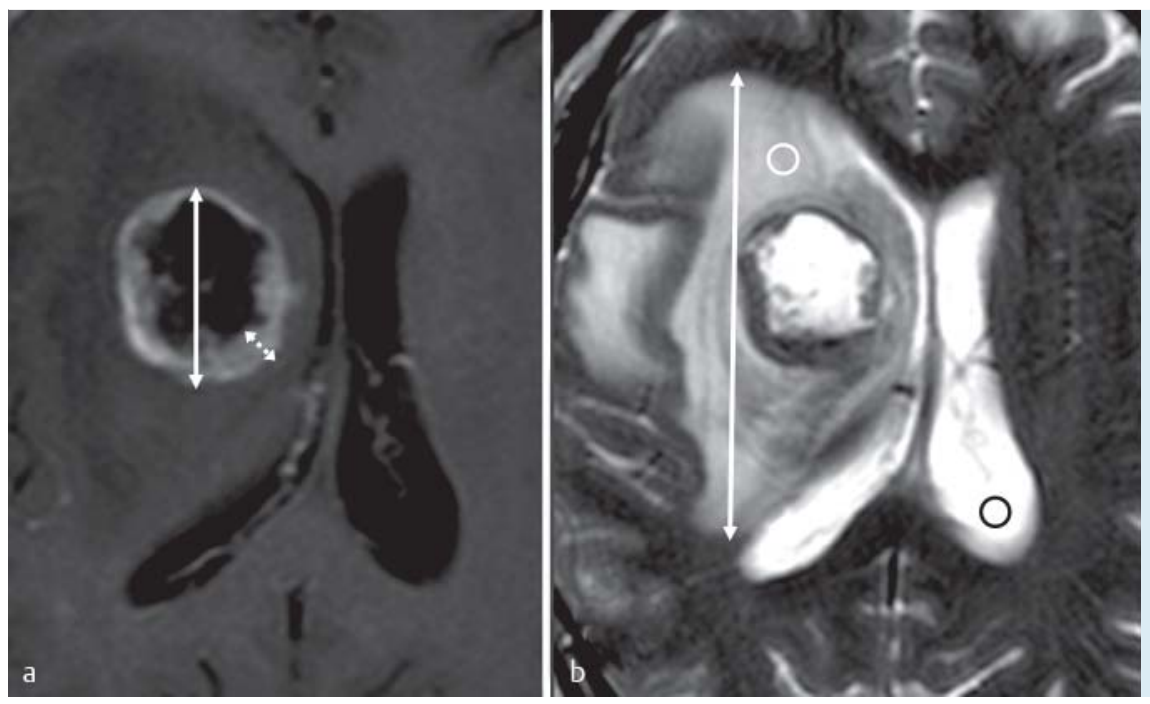

Fig. 2 Examples for image analysis: Assessment of maximum diameter of enhancing mass area and maximum thickness of enhancing rim (dotted arrow) on T1w sequences post contrast medium a; maximum diameter of peritumoral area and signal intensity of peritumoral area (white ring) relative to that of cerebrospinal fluid (black ring) on T2w sequences $\mathbf{b}$.

Abb. 2 Beispiele für die Bildanalyse: Erfassung des maximalen Durchmessers der kontrastmittelaufnehmenden Tumormasse und der Dicke des Randsaums (gepunkteter Pfeil) auf T1w-Sequenzen post Kontrastmittelgabe a; maximaler Durchmesser des peritumoralen Areals und Signalintensitäten der peritumoralen Zone (weißer Ring) in Relation zu derjenigen von Liquor (schwarzer Ring) in T2w-Sequenzen $\mathbf{b}$.

Table 2 Morphologic criteria investigated in the study (7) and signal intensities (6).

Tab. 2 Einbezogene morphologische Kriterien (7) und Signalcharakteristika (6)

\begin{tabular}{|c|c|}
\hline morphologic criteria (7) & unit \\
\hline maximum extent of the contrast-enhancing area & $\mathrm{mm}$ \\
\hline minimum extent of the contrast-enhancing area & $\mathrm{mm}$ \\
\hline maximum thickness of the enhancing margin & $\mathrm{mm}$ \\
\hline enhancing area involves the cortex & yes/no \\
\hline $\begin{array}{l}\text { maximum extent of perifocal edema } \\
\text { (T2w hyperintensity) }\end{array}$ & $\mathrm{mm}$ \\
\hline $\begin{array}{l}\text { minimum extent of perifocal edema } \\
\text { (T2w hyperintensity) }\end{array}$ & $\mathrm{mm}$ \\
\hline mass effect of single lesion & $\begin{array}{l}\text { absent/moderate/ } \\
\text { severe }\end{array}$ \\
\hline signal intensity (6) & unit \\
\hline signal intensity of edema relative to CSF & $\begin{array}{l}\text { dimensionless } \\
\text { number }\end{array}$ \\
\hline $\begin{array}{l}\text { proportion of lesion with increased signal } \\
\text { intensity on T1w SE image (pre-contrast) }\end{array}$ & percentage \\
\hline $\begin{array}{l}\text { proportion of lesion with increased signal } \\
\text { intensity on T2W TSE image (pre-contrast) }{ }^{1} \\
\text { proportion of lesion with increased signal } \\
\text { intensity on FLAIR image (pre-contrast) }{ }^{1}\end{array}$ & $\begin{array}{l}\text { percentage } \\
\text { percentage }\end{array}$ \\
\hline $\begin{array}{l}\text { proportion of lesion with increased signal } \\
\text { intensity on T2w FFE image (pre-contrast) }{ }^{1}\end{array}$ & percentage \\
\hline $\begin{array}{l}\text { proportion of lesion with increased signal } \\
\text { intensity on diffusion-weighted imaging }\end{array}$ & percentage \\
\hline
\end{tabular}

${ }^{1}$ Compared with normal contralateral brain tissue.

\section{Image analysis}

The images of all patients were analyzed for the following morphologic criteria ( Table 2, $\bullet$ Fig. 2): Maximum and minimum diameter of enhancing mass area, maximum thickness of enhancing rim and cortical involvement (yes/no) on T1w post-contrast sequences; maximum and minimum diameter of peritumoral area, mass effect (absent/moderate/severe) on T2-weighted images. The signal intensity of the peritumoral area relative to that of the cerebrospinal fluid (CSF) was evaluated on T2-weighted images. In addition, the signal intensities of the mass area on T1-weighted, T2weighted, FLAIR, T2 FFE, and DWI images were compared to a contralateral area of healthy brain parenchyma. The images were ana- lyzed in consensus by two readers blinded to the histologic diagnosis, clinical data, age, and sex (E.W. and M.M.).

\section{Statistical analysis}

Statistical analysis was performed with SAS 9.2 (SAS Institute Inc., Cary, NC, USA). Quantitative values are given as means with standard deviations, and qualitative values as proportions and percentages. Logistic regression was used based on histopathology as the standard of reference. Stepwise elimination of nonsignificant factors with a level of significance of $5 \%$ (two-sided) led to the final model. Odds ratios were calculated for significant factors along with $95 \%$ confidence intervals (Wald approach). Receiveroperating characteristic (ROC) analysis was used to select an optimal cut-off point for prediction and to assess the predictive value in terms of the sensitivity, specificity, and accuracy of the final model. The selection of the optimal cut-point was based on the Youden index, i.e., the maximum sum of sensitivity and specificity. $95 \%$ confidence intervals were calculated for the diagnostic parameters using Fieller's theorem. The 95\% confidence interval for the AUC was calculated by bootstrapping.

\section{Results}

\section{$\nabla$}

The study included 95 patients with a single supratentorial ringenhancing cerebral lesion on MRI. There were 51 patients with GBM (mean age, $62.4 \pm 12.8$ years; range, $11-84$ years; 29 men, 22 women) and 44 patients with a single supratentorial metastasis (mean age, 60.2 \pm 12.4 years; range, 29 - 79 years; 22 men, 22 women). In the group of patients with cerebral metastasis, histology revealed the following primary tumors: 18 malignant melanomas (without hyperintensities on native T1-weighted images), 16 gastrointestinal adenocarcinomas, 3 bronchial carcinomas, 3 renal cell carcinomas, 2 breast cancers, 1 ovarian cancer, and 1 differentiated neuroendocrine tumor ( $\bullet$ Table 1$)$.

Analysis of all morphologic criteria investigated revealed that only the ratio of the maximum diameter of the peritumoral area measured on T2-weighted images $\left(\mathrm{d}_{\mathrm{T} 2}\right)$ to the maximum diameter of the enhancing mass area $\left(\mathrm{d}_{\mathrm{T} 1 \text {, post-contrast }}\right)$ had a predictive value for differentiating solitary supratentorial metastasis and GBM with a lower ratio favoring GBM. None of the other criteria like enhancing tumor size, thickness of the enhancing rim, cen- 


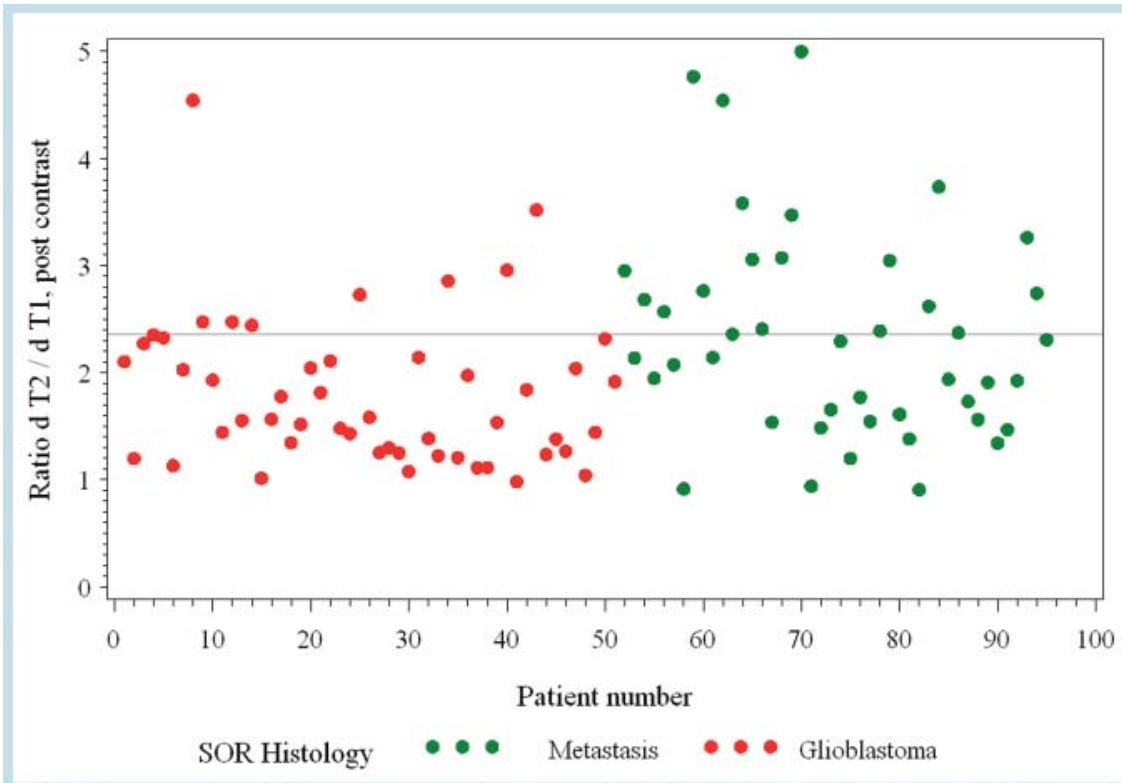

Fig. 3 Plot of ratio of the maximum diameter of the peritumoral area measured on T2-weighted images to the maximum diameter of the enhancing mass area by patient; numbers 1 to 51 correspond to patients with GBM, numbers 52 to 95 correspond to patients with metastases; cut-off $=2.35$ (horizontal line).

Abb.3 Darstellung der Verhältnisse aus maximalem peritumoralen Areal in T2-gewichteten Sequenzen und maximalem Durchmesser der Kontrastmittel auf-nehmenden Tumormasse; Punkte 1 - 51 entsprechen den Patienten mit einem Glioblastom, Punkte 52 - 95 Patienten mit einer Metastase; Schwellenwert =2,35 (horizontale Linie).

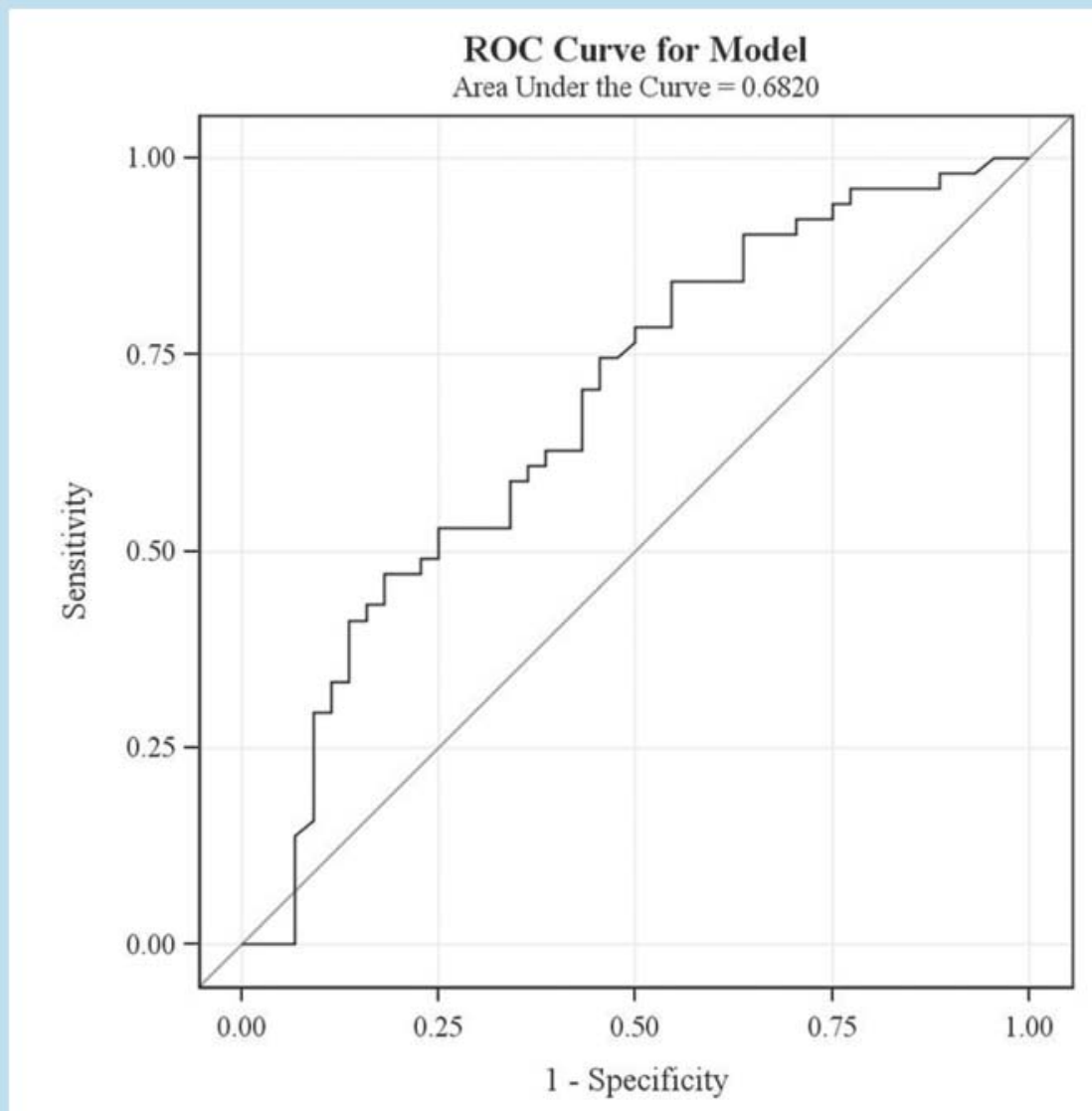

Fig. 4 ROC curve for the final model with explaining factor ratio $\mathrm{d} T 2 / \mathrm{d} T 1$, post-contrast.

Abb.4 ROC-Kurve für das finale Modell mit dem Verhältnisfaktor d T2/d T1, post contrast.

tral signal intensity on FLAIR or DWI alone or in combination turned out to contribute to the differential diagnosis of these two entities.

The ratios of $\mathrm{d}_{\mathrm{T} 2} / \mathrm{d}_{\mathrm{T} 1 \text {, post-contrast }}$ for metastases and GBM were found to differ with mean ratios of $2.34( \pm 0.98)$ and $1.81( \pm 0.70)$, respectively. The final logistic model can be expressed as follows:

$\log [\pi /(1-\pi)]=1.7870-0.8031 \times\left(\mathrm{d}_{\mathrm{T} 2} / \mathrm{d}_{\mathrm{T} 1 \text {, post-contrast }}\right)$ where $\pi$ is the probability of GBM and $d$ is the maximum diameter of the peritumoral area and the mass area.

The accuracy of the final model was found to be $68 \%$ (95\% CI $57 \%$; $78 \%$ ) with a sensitivity of $84 \%$ (95\% CI $71 \%$; $93 \%$ ) and a specificity of $45 \%$ (95\% CI 30\%; $61 \%$; $\odot$ Fig. 3, 4).

A cut-off for the probability of 0.47411 on the logistic scale corresponds to a cut-off for the ratio $\mathrm{d}_{\mathrm{T} 2} / \mathrm{d}_{\mathrm{T} 1 \text {, post-contrast }}$ of 2.35 , i. e., if a lesion shows a ratio of less than 2.35 , it is correctly classified as 
GBM in $64 \%$ (95\% CI 52\%; 76\%) of cases (positive predictive value, - Fig. 3). If a lesion shows a ratio of more than 2.35 , it is correctly classified as metastasis in $71 \%$ (95\% CI $51 \%$; $87 \%$ ) of cases (negative predictive value).

\section{Discussion}

\section{$\nabla$}

A patient's history often provides important clues for differentiating GBM and cerebral metastasis. When a patient has extracranial malignant disease, MRI detection of multiple sharply demarcated brain lesions with ring enhancement or infratentorial lesions favors the diagnosis of metastasis, although multifocal GBM have been reported in the literature [17]. On the other hand, one must bear in mind that brain metastasis is the first clinically apparent manifestation of a systemic tumor in up to $30 \%$ of patients with $25-50 \%$ of brain metastases occurring as single lesions $[18,19]$ and histological confirmation is necessary with a considerable risk of morbidity and mortality [20]. An exception is cerebral metastasis from malignant melanoma, where melanin or blood products appear hyperintense on unenhanced T1-weighted images and may suggest the primary tumor [21]. Our results show that most morphologic criteria and signal intensity characteristics are of limited use for differentiating solitary supratentorial brain metastasis from GBM. Even the combination of different criteria does not improve accuracy. In our study, the high T2 and FLAIR signal intensity of the peritumoral area surrounding the ring-enhancing lesion relative to the signal intensity of CSF also failed to contribute to the differential diagnosis. This is surprising as one would expect differences in the $\mathrm{T} 2$ and FLAIR signal intensities of the reactive vasogenic edema in the case of metastasis as opposed to the tumor infiltration in the case of GBM [22 - 24]. Tang et al. [12] studied the diagnostic utility of FLAIR in assessing for non-enhancing cortical intensity abnormality to distinguish GBM from solitary metastases and found a sensitivity and specificity of $44 \%$ and $91 \%$, respectively. In addition, gadolinium-enhanced FLAIR imaging was shown to allow markedly increased lesion delineation [25 - 27].

Also the irregular peripheral enhancement with an unenhanced central necrosis of GBM as opposed to nodular or ring-like enhancement of metastasis is not a specific finding. Nevertheless, this criterion may be based on a bias since the delay after contrast medium application and the contrast dose have a direct impact on the tumor [28]. It was shown that the tumor volume of gliomas increases by continuous contrast uptake of the peripheral parts between 4 and 20 minutes after contrast injection [29]. However, a double dose of gadolinium allows a higher diagnostic yield in the detection of metastases [30 - 32].

A logistic regression analysis revealed that the only factor of value turned out to be the size ratio of the peritumoral T2 high signal intensity area to the enhancing mass area. The accuracy of $68 \%$ (sensitivity of $84 \%$ and specificity of $45 \%$ ) we found for this strictly morphologic criterion is only slightly below that reported by others for advanced quantitative MRI techniques such as spectroscopy, diffusion tensor imaging and perfusion imaging [7, 10, 33]. Notably, Young et al. reported a sensitivity of $88 \%$ and a specificity of $72 \%$ for an echo-planar perfusion-weighted imaging technique [14], while Opstad et al. found a specificity of $80 \%$ and a sensitivity of $80 \%$ for MR spectroscopy [7]. Further studies using DTI to differentiate between glioblastomas and metastases found the fractional anisotropy (FA), as a measure of the degree of directionality of diffusion, to be significantly lower within the edema surrounding metastases, whereas the mean diffusivity (MD), as a measure of the overall magnitude of diffusion, was significantly higher in the edema around metastases $[34,35]$. When DTI metrics from the tumor volume and the surrounding peritumoral edema were combined, Byrnes et al. [35] were able to correctly predict $87 \%$ of glioblastomas and $83 \%$ of metastases.

A limitation of this study is the small sample size so that factors with lesser effects on the differentiating of metastases and GBM might not have been detected and also important combinations of factors might have been missed. Overall, with small sample sizes only factors with a strong effect have a high probability to be detected in such analysis. On the other hand, if a factor is found to be a significant contributor to the differentiation of GBM and metastases with a small sample size, then this leads to the suggestion that this factor is important with high confidence.

\section{Conclusion}

Our systematic analysis of a variety of morphologic criteria and signal intensities revealed the ratio of maximum diameter of the peritumoral area measured on T2-weighted images to the maximum diameter of the enhancing mass area to be the only useful factor for differentiating single supratentorial brain metastasis from GBM. With an accuracy of $68 \%$, this feature is comparable to advanced MRI techniques and is easy to evaluate despite the time constraints encountered in clinical practice.

\section{References}

1 Louis DN, Ohgaki H, Wiestler OD et al. The 2007 WHO classification of tumours of the central nervous system. Acta Neuropathol 2007; 114: 97-109

2 Giese A, Westphal M. Treatment of malignant glioma: a problem beyond the margins of resection. J Cancer Res Clin Oncol 2001; 127: $217-225$

3 Claes A, Idema AJ, Wesseling P. Diffuse glioma growth: a guerilla war. Acta Neuropathol 2007; 114: 443-458

4 Peters S, Knoss N, Wodarg F et al. Glioblastomas vs. Lymphomas: More Diagnostic Certainty by Using Susceptibility-Weighted Imaging (SWI). Fortschr Röntgenstr 2012; 184: 713-718

5 Mönninghoff C, Maderwald S, Theysohn JM et al. Imaging of brain metastases of bronchial carcinomas with 7 T MRI - initial results. Fortschr Röntgenstr 2010; 182: $764-772$

6 Devos A, Lukas L, Suykens JA et al. Classification of brain tumours using short echo time 1H MR spectra. J Magn Reson 2004; 170: 164-175

7 Opstad KS, Murphy MM, Wilkins PR et al. Differentiation of metastases from high-grade gliomas using short echo time $1 \mathrm{H}$ spectroscopy. J Magn Reson Imaging 2004; 20: 187-192

8 Chiang IC, Kuo YT, Lu CY et al. Distinction between high-grade gliomas and solitary metastases using peritumoral 3-T magnetic resonance spectroscopy, diffusion, and perfusion imagings. Neuroradiology 2004; 46: 619-627

9 Lu S, Ahn D, Johnson G et al. Peritumoral diffusion tensor imaging of high-grade gliomas and metastatic brain tumors. Am J Neuroradiol 2003; 24: 937-941

10 Law M, Cha S, Knopp EA et al. High-grade gliomas and solitary metastases: differentiation by using perfusion and proton spectroscopic MR imaging. Radiology 2002; 222: 715-721

11 Cho SK, Na DG, Ryoo JW et al. Perfusion MR imaging: clinical utility for the differential diagnosis of various brain tumors. Korean J Radiol 2002; 3: $171-179$

12 Tang YM, Ngai S, Stuckey S. The solitary enhancing cerebral lesion: can FLAIR aid the differentiation between glioma and metastasis? Am J Neuroradiol 2006; 27: 609-611

13 Stuckey SL, Wijedeera R. Multicentric/multifocal cerebral lesions: can fluid-attenuated inversion recovery aid the differentiation between glioma and metastases? J Med Imaging Radiat Oncol 2008; 52: 134 139

14 Young GS. Advanced MRI of adult brain tumors. Neurol Clin 2007; 25 : $947-973$ 
15 Korn A, Braun C, Fenchel M et al. Bildgebendes MRT-Response-Monitoring bei Glioblastoma multiforme während der Therapie mit Bevacizumab. Fortschr Röntgenstr 2012; 184: 397-401

16 Duygulu G, Ovali GY, Calli C et al. Intracerebral metastasis showing restricted diffusion: correlation with histopathologic findings. Eur J Radiol 2010; 74: 117-120

17 Barnard RO, Geddes JF. The incidence of multifocal cerebral gliomas. A histologic study of large hemisphere sections. Cancer 1987; 60: 1519_ 1531

18 Schiff D. Single Brain Metastasis. Curr Treat Options Neurol 2001; 3: 89-99

19 Sze G, Milano E, Johnson C et al. Detection of brain metastases: comparison of contrast-enhanced MR with unenhanced MR and enhanced CT. Am J Neuroradiol 1990; 11: 785-791

20 Bernstein M, Parrent AG. Complications of CT-guided stereotactic biopsy of intra-axial brain lesions. J Neurosurg 1994; 81: 165-168

21 Gaviani P, Mullins ME, Braga TA et al. Improved detection of metastatic melanoma by $\mathrm{T}^{*}$-weighted imaging. Am J Neuroradiol 2006; 27: $605-608$

22 Zhang $M$, Olsson $Y$. Hematogenous metastases of the human brain characteristics of peritumoral brain changes: a review. J Neurooncol 1997; 35: $81-89$

23 Lehmann P, Saliou G, de Marco G et al. Cerebral peritumoral oedema study: Does a single dynamic MR sequence assessing perfusion and permeability can help to differentiate glioblastoma from metastasis? Eur J Radiol 2011, Feb 18 Epub ahead of print

24 Ringelstein A, Turowski B, Gizewski ER et al. Evaluation des ADC-Mappings als Prädiktor für ein Ansprechen von Glioblastomrezidiven auf eine Therapie mit Avastin. Fortschr Röntgenstr 2010; 182: 868-872. DOI: $10.1055 / \mathrm{s}-0029-1245570$

25 Essig M, Knopp MV, Schoenberg SO et al. Cerebral gliomas and metastases: assessment with contrast-enhanced fast fluid-attenuated inversion-recovery MR imaging. Radiology 1999; 210: 551 - 557
26 Ercan N, Gultekin S, Celik H et al. Diagnostic value of contrast-enhanced fluid-attenuated inversion recovery MR imaging of intracranial metastases. Am J Neuroradiol 2004; 25: 761 - 765

27 Mathews VP, Caldemeyer KS, Lowe MJ et al. Brain: gadolinium-enhanced fast fluid-attenuated inversion-recovery MR imaging. Radiology 1999; 211: 257-263

28 Yuh WT, Tali ET, Nguyen HD et al. The effect of contrast dose, imaging time, and lesion size in the MR detection of intracerebral metastasis. Am J Neuroradiol 1995; 16: 373-380

29 Engelhorn T, Schwarz MA, Eyupoglu IY et al. Dynamic contrast enhancement of experimental glioma an intra-individual comparative study to assess the optimal time delay. Acad Radiol 2010; 17: 188-193

30 Schneider G, Kirchin MA, Pirovano G et al. Gadobenate dimeglumineenhanced magnetic resonance imaging of intracranial metastases: effect of dose on lesion detection and delineation. J Magn Reson Imaging 2001; 14: 525-539

31 Kim ES, Chang JH, Choi HS et al. Diagnostic yield of double-dose gadobutrol in the detection of brain metastasis: intraindividual comparison with double-dose gadopentetate dimeglumine. Am J Neuroradiol 2010; 31: $1055-1058$

32 Ba-Ssalamah A, Nöbauer-Huhmann IM, Pinker K et al. Effect of contrast dose and field strength in the magnetic resonance detection of brain metastases. Invest Radiol 2003; 38: 415-422

33 Cha S, Lupo JM, Chen MH et al. Differentiation of glioblastoma multiforme and single brain metastasis by peak height and percentage of signal intensity recovery derived from dynamic susceptibility-weighted contrast-enhanced perfusion MR imaging. Am J Neuroradiol 2007; 28: $1078-1084$

34 Wang S, Kim S, Chawla S et al. Differentiation between glioblastomas, solitary brain metastases, and primary cerebral lymphomas using diffusion tensor and dynamic susceptibility contrast-enhanced MR imaging. Am J Neuroradiol 2011; 32: 507 - 514. DOI: 10.3174/ajnr.A2333

35 Byrnes TJ, Barrick TR, Bell BA et al. Diffusion tensor imaging discriminates between glioblastoma and cerebral metastases in vivo. NMR in biomedicine 2011; 24: 54-60. DOI: 10.1002/nbm.1555 